\title{
Effect of incorporation of flours on the functional properties of composite flours
}

\author{
Rajmani Prajapati, Suresh Chandra, Samsher, Neelash Chauhan, GR Singh \\ and Sandeep Kumar ${ }^{1}$
}

Department of Agricultural Engineering and Food Technology, SVPUA\&T, Meerut-250110

${ }^{1}$ Department of Biochemistry \& Physiology, College of Biotechnology, SVPUA\&T, Meerut-250110

\begin{abstract}
The present investigation was carried out to study the effect of incorporation of different flour on the functional properties of composite flours. Wheat flour was incorporated with mushroom flour, black gram flour, soya flour and jowar (sorghum) flour blends in ratios of 100:0:0:0:0, 90:2.5:2.5:2.5:2.5, 80:5.0:5.0:5.0:5.0 and 70:7.5:7.5:7.5:7.5, respectively. Wheat flour of the ratio of 100:0:0:0:0 was considered as control. The physical and functional properties of individual and composite flours were analyzed. Swelling water capacity, water absorption capacity and foam stability was increased while foam capacity, oil absorption capacity, emulsion activity, emulsion stability and bulk density decreased with increasing the level of incorporation other flours. Same trend was found in the ash content which was increased with increasing the level of incorporation and moisture content as vice-versa.
\end{abstract}

Keywords: Functional properties, swelling water capacity, water absorption capacity, foam stability, foam capacity, oil absorption capacity, emulsion activity, emulsion stability.

Paper cited: Prajapati, R., Chandra, S., Samsher; Chauhan, N., Singh, G.R. and Kumar, S. (2015). Effect of incorporation of flours on the functional properties of composite flours. South Asian Journal of Food Technology and Environment, 1(3\&4): 233-241.

Received: 15/09/2015 Revised: 29/09/2015 Accepted 3/10/2015

\section{Introduction}

Cereals are an excellent source of vitamins and minerals including fat-soluble vitamin $\mathrm{E}$, which is an essential antioxidant. The cereal grains easily supply quantity of protein as required for RDA but unfortunately they lack the essential amino acid lysine and therefore they must not to be used as the sole source of dietary protein (Khatkar, 2005). Cereal grains like wheat, corn, rice, barley, sorghum, etc. provide $68 \%$ of the total world food supplies. Wheat is mainly used as a dietary staple, averaging two-thirds of total consumption (Anjum et al., 2005).

No legume or cereal alone can provide adequate amounts of all nutrients to meet the nutritional requirements of human being. However, even before knowledge on protein content, protein quality, digestibility and the nutrient requirements of humans became available, it was recognized that mixing legumes with cereals in the diet could improve overall nutrition. The present and newly derived knowledge in these areas makes it possible to blend, mix or fortify one food material with others so that the resulting fortified mix has not only better nutritional quality but also the necessary attributes for consumer acceptance. Protein malnutrition is a serious problem in undeveloped countries due to cereal based dietary pattern therefore various preparation based on cereal pulse combination are of paramount importance to improve the protein quality of human diet. (Ruales and Nair, 1992).

Composite flour technology refers to the process of mixing various flours to make use of local raw material to produce high quality food products in an economical way. Formulation of composite flour is vital for development of value-added products with optimal functionality (Rehman et al., 2007). Owing to shortage of wheat, several 
developing countries have devised programs to assess the feasibility of alternate sources for substituting or blending with wheat flour. (Khader, 2001). Iyer and Singh (1997) explained the composite flours containing wheat and legumes are being utilized in many parts of the world.

Several studies about the influence of the addition of legume flours on the functional properties of bread dough and final bread quality have been reported in the last 30 years. The use composite flour based on wheat and other cereals including minor millets in bakery products is becoming popular because of the economic and nutritional advantages (Dasappa et al., 2004). Therefore, efforts are being made to partially replace wheat flour with non-wheat flours as a possibility for increasing the utilization of indigenous crops cultivated in many countries as well as contribute to lowering cost of bakery products (Ayo and Gaffa, 2002). The combination of grain with legume proteins would provide better overall essential amino acid balance, helping to overcome the world protein calorie malnutrition problem (Livingstone et al., 1993). Bakery products are varied by addition of value added ingredients. Among the added ingredients, dietary fiber has gained tremendous attention (Shuda et al., 2007). Attempts have been made to substitute wheat with other flours such as cow pea (Okaka and Isieh, 1990; Akubor et al., 2003a; Akubor, et al., 2003b), amaranth grain (Adeyemi et al., 1992; Ayo, 2001) and African bread fruit (Akubor and Badifu, 2004). Similarly, mixtures of non-wheat flours such as millet/pigeon pea (Eneche, 1999), Cowpea/maize (Akubor et al., 2001), cowpea/plantain (Akubor et al., 2003a), wheat/cassava / maize/cowpea blends (Oladunmaye et al., 2010), Aestivum wheat bran/durum wheat bran (Ghobel et al., 2010) and wheat/rice/mung/potato flour (Chandra et al., 2015) have been evaluated the functional properties. Since the available literature on functional properties of composite flours made from wheat, mushroom, black gram, soybean and sorghum flour is rather scanty. The present study was undertaken to develop the composite flour and analysis their functional properties for industrial information and utilization.

\section{Materials and Methods}

Raw materials viz., Wheat flour (maida), Mushroom flour, Blackgram flour, Soya flour and jowar flour and Chemicals and other desired materials etc. were procured from local market of Meerut (UP) India for the present study. The entire studies were conducted in the Department of Agricultural Engineering and Food Technology, S.V.P. University of Agric. \& Tech., Meerut (U. P.). Instruments / equipment used were knife, trays, grinder, whiley mill, sieve, electronic balance, hot air oven, centrifuge, desiccator, water bath, test tube and measuring cylinder etc. Composite flour was made from refined wheat flour, mushroom flour, black gram flour, full fat soya flour and jowar (sorghum) flour. Detailed methodology of development of each flour and composite flour is given below:

\section{Development of flours}

Refined wheat flour (maida): Refined wheat flour (Rajdhani brand) was manufactured from Victoria Food (P) Ltd, New Delhi. Refined flour was free from any artificial additives and preservative.

Mushroom flour: Mushroom flour was manufactured from Division of Post Harvest Technology, National Research Centre for Mushroom (NRCM), Chambaghat, Distt. Solan, Himachal Pradesh (India) which was free from any artificial additives and preservatives.

Black gram flour: Black gram bean was procured from the market and removed all the impurities, damaged and infested grain by manual cleaning. The cleaned black gram bean was soaked overnight to destroy the antinutritional factor and loosening the husk. 
Soaked black gram bean was dried for 3-4 days in sun up to very low moisture content and ground by domestic Atta chakki into two passes. Black gram flour was also sieved.

Soya bean flour: Soya bean was procured, cleaned and soaked overnight to destroy the anti-nutritional factor. Soaked Soya bean was dried for 3-4 days in sun up to very low moisture content and ground by domestic Atta chakki into two passes was also sieved.

Jowar (sorghum) flour: Jowar was procured from the market and cleaned manually. The cleaned Jowar was soaked overnight then dried up to 3-4 days in sunlight desired moisture content and ground by domestic Atta chakki into two passes and sieved also.

Composite flours: Composite flours were prepared from wheat flour incorporating with mushroom flour, black gram flour, soya flour and jowar (sorghum) flour blends in ratios of 100:0:0:0:0, 90:2.5:2.5:2.5:2.5, 80:5.0:5.0: 5.0:5.0 and 70:7.5:7.5:7.5:7.5, respectively. Wheat flour of the ratio of 100:0:0:0:0 were considered as control.

\section{Evaluation of physico-chemical properties of flours}

Moisture content (M.C.): Initial moisture content of samples was determined by hot air oven drying method as recommended by AOAC (2000).

Ash content (\%): Ash content was determined by the method as recommended by (BIS, 1977), standard methods for the examination of flours and flour products. In a clean silica dish, $5 \mathrm{~g}$ of homogenous sample of flour was weighed and $6 \mathrm{ml}$ of nitric acid was added and heated at low fire until the changing of colour was completed. Thereafter, silica dish was transferred to an electric furnace maintained at a temperature of about $850 \pm 20^{\circ} \mathrm{C}$ and ignite till carbon free. The dish was cooled down in desiccators and weighed. The process was repeated till constant weight was obtained.

$$
\operatorname{Ash}(\%)=\frac{W_{2}-W_{1}}{W} \times 100
$$

Where,

$\mathrm{W}=$ weight of sample, $(\mathrm{g}), \mathrm{W}_{1}=$ weight of silica dish $(\mathrm{g}), \mathrm{W}_{2}=$ weight of silica dish + ash (g)

2.2.3 Bulk density: The volume of $100 \mathrm{~g}$ of the flours was measured in a measuring cylinder (250 ml.) after tapping the cylinder on a wooden plank until no visible decrease in volume was noticed, and based on the mass and volume, the apparent (bulk) density was calculated (Jones et. al., 2000).

\section{Assessment of functional properties of flours}

Swelling capacity: The swelling capacity was determined by the method described by (Okaka and Potter, 1977). $100 \mathrm{ml}$ graduated cylinder was filled with the flour to $10 \mathrm{ml}$ mark. The distilled water was added to give a total volume of $50 \mathrm{ml}$. The top of the graduated cylinder was tightly covered and mixed by inverting the cylinder. The suspension was inverted again after $2 \mathrm{~min}$ and left to stand for a further $8 \mathrm{~min}$. The volume occupied by the flour was taken after the $8^{\text {th }}$ $\min$.

Water absorption capacity (mg/100 gm): The water absorption capacity was determined by the method of (Sosulski et al., 1976). One gram of flour mixed with $10 \mathrm{ml}$ distilled water and allow to stand at ambient temperature $\left(30 \pm 2^{\circ} \mathrm{C}\right)$ for $30 \mathrm{~min}$ and centrifuged for 30 min at $3000 \mathrm{rpm}$ or $2000 \mathrm{x} \mathrm{g}$. Water absorption was examined as percent water bound per gram flour.

Fat (oil) absorption capacity (mg /100 gm): The fat absorption capacity was determined by the method of (Sosulski et al., 1976). One gram of flour mixed with $10 \mathrm{ml}$ soybean oil (Sp. gravity: 0.9092) and allows to stand at ambient temperature $\left(30 \pm 2{ }^{0} \mathrm{C}\right)$ for $30 \mathrm{~min}$, then centrifuged for $30 \mathrm{~min}$ at $3000 \mathrm{rpm}$ or 
2000 x g. Fat/oil absorption capacity was examined as percent fat/oil bound per gram flour.

Emulsion activity (\%) and Emulsion stability (\%): The emulsion activity and stability were determined by the method of (Yasumatsu et al., 1972). The emulsion (1.0 g flour, $10 \mathrm{ml}$ distilled water and $10 \mathrm{ml}$ soybean oil) was mixed in calibrated centrifuged tube. The emulsion was centrifuged at $2000 \mathrm{~g}$ for $5 \mathrm{~min}$. The ratio of the height of emulsion layer to the total height of the mixture was calculated as emulsion activity in percentage. The emulsion stability was estimated after heating the emulsion contained in calibrated centrifuged tube at $80^{\circ} \mathrm{C}$ for $30 \mathrm{~min}$ in a water-bath, cooled for 15 min under running tap water and centrifuged at $2000 \mathrm{~g}$ for $15 \mathrm{~min}$. The emulsion stability expressed as percentage was calculated as the ratio of the height of emulsified layer to the total height of the mixture.

Foam capacity (\%) and Foam stability (\%): The foam capacity (FC) and Foam stability (FS) were determined as described by (Narayana and Narasinga Rao, 1982) with minute modification. The $1.0 \mathrm{~g}$ flour sample was added to $50 \mathrm{ml}$ distilled water at $30 \pm 2^{\circ} \mathrm{C}$ in a graduated cylinder. The suspension was mixed and shaken for $5 \mathrm{~min}$ to foam development. The volume of foam at $30 \mathrm{sec}$ after whipping was expressed as foam capacity using the formula:

$$
\begin{aligned}
& \text { Foam capacity (\%) } \\
& =\frac{\text { Volume of foam AW }- \text { Volume of foam BW }}{\text { Volume of foam BW }} \times 100
\end{aligned}
$$

Where, whipping

$\mathrm{AW}=$ after whipping, $\mathrm{BW}=$ before

The volume of foam was recorded one hour after whipping to determine foam stability as per percent of initial foam volume.

\section{Statistical analysis}

The data obtained from the various experiments was done by using ANOVA with Factorial Randomized Block Design (factorial R.B.D.). The significance difference between the means was tested against the critical difference at $5 \%$ level of significance (Gomez and Gomez, 1984). STATPAC (OPSTAT) software was used for analyze the recorded data.

\section{Results and Discussion}

\section{Physico-chemical properties of flours}

The mushroom flour indicated highest moisture content (14.84\%) is followed by refined wheat flour show $13.467 \%$ but black gram flour showed lowest moisture content 9.903\% amongst individual flours. With increase incorporation levels viz., $2.5 \%, 5 \%$ and $7.5 \%$, the moisture content of mixed flour is decreased with values $14.127 \%, 13.807 \%$ and $13.227 \%$ respectively (Table 1 ).

From Table 1, it can be noticed that the mushroom flour had highest ash content $(10.061 \%)$ followed by full fatted soya flour $(4.193 \%)$ but refined wheat flour showed very low ash content $(0.75 \%)$ as compared to others. If mushroom flour, black gram flour, full fat soya flour and jowar (sorghum) was mixed with refined wheat flour in the composition $2.5 \%, 5 \%$ and $7.5 \%$, the ash content of composite flour increased significantly to $0.943 \%, 1.217 \%$ and $1.555 \%$ with increasing the level of incorporation of flours. From the nutritional point of view it is an important parameter for the fortification of cereals products. The similar results have been reported by (Mojisola et al., 2005) for maize soybean blend. The percentage of ash content increased significantly with increases the fortification of flours.

The black gram flour showed highest value of bulk density $(0.90 \mathrm{~g} / \mathrm{cc})$ followed by 
jowar (sorghum) flour $(0.842 \mathrm{~g} / \mathrm{cc})$ while full fatted soy flour had $0.701 \mathrm{~g} / \mathrm{cc}$. The bulk density of composite flours decreased to 0.787 $\mathrm{g} / \mathrm{cc}, 0.790 \mathrm{~g} / \mathrm{cc}$ and $0.792 \mathrm{~g} / \mathrm{cc}$ respectively with an increase in the level of flours. The results indicated that the bulk density of defatted flours is less than full fatted flours. Similar results were reported by (Chau et al., 1997) in legumes. Same work by (Amarjeet et al., 1993) described the bulk densities of different flour blends are lower as compared to wheat blends.

Table 1: Physico-chemical Properties of flours

\begin{tabular}{|c|c|c|c|}
\hline Samples & Moisture content, \% & Ash content, \% & Bulk density, g/cc \\
\hline \multicolumn{4}{|c|}{ Individual flours } \\
\hline $\mathrm{M}_{100}$ & $14.84 \pm 0.06$ & $10.061 \pm 0.13$ & $0.725 \pm 0.01$ \\
\hline $\mathrm{B}_{100}$ & $9.903 \pm 0.12$ & $2.649 \pm 0.16$ & $0.901 \pm 0.01$ \\
\hline$S_{100}$ & $10.673 \pm 0.57$ & $4.193 \pm 0.15$ & $0.701 \pm 0.01$ \\
\hline $\mathrm{J}_{100}$ & $12.633 \pm 0.32$ & $1.403 \pm 0.04$ & $0.842 \pm 0.01$ \\
\hline $\mathrm{W}_{100}$ & $13.467 \pm 0.53$ & $0.75 \pm 0.09$ & $0.84 \pm 0.07$ \\
\hline \multicolumn{4}{|c|}{ Composite flours } \\
\hline $\mathrm{W}_{90} \mathrm{CF}_{2.5}$ & $14.127 \pm 0.09$ & $0.943 \pm 0.04$ & $0.787 \pm 0.01$ \\
\hline $\mathrm{W}_{80} \mathrm{CF}_{5}$ & $13.807 \pm 0.35$ & $1.217 \pm 0.10$ & $0.790 \pm 0.01$ \\
\hline $\mathrm{W}_{70} \mathrm{CF}_{7.5}$ & $13.227 \pm 0.55$ & $1.555 \pm 0.12$ & $0.792 \pm 0.01$ \\
\hline $\mathrm{CD}_{0.5}$ & 0.609 & 0.189 & 0.084 \\
\hline SEm \pm & 0.199 & 0.062 & 0.016 \\
\hline
\end{tabular}

Values: Mean \pm SD

\section{Functional properties of flours}

The flours were prepared and to study the swelling water capacity (SWC), water absorption capacity (WAC), foam capacity, foam stability, fat/oil absorption capacity, emulsion activity and emulsion stability.

Swelling water capacity: Table 2 shows that black gram flour represented maximum swelling water capacity $43 \%$ followed by mushroom flour $27.667 \%$ and lowest was found in jowar flour $15.667 \%$. If mushroom flour, black gram flour, full fat soya flour and jowar (sorghum) blends with refined wheat flour in the composition of $2.5 \%, 5 \%$ and $7.5 \%$, the swelling water capacity increased $16.333 \%, 17.333 \%$ and $19.333 \%$, respectively. These occur due to hydrophilic interaction between water and protein molecules by hydrogen bonding. Swelling water capacity of the composite flour gives it an advantage of being used as a thickener in liquid and semiliquids foods since the flours has the ability to absorb water and swell for improved consistency in biscuits. Similar research were reported by (Osundahunsi et al., 2003) for maize, sweet potato flour blends and for soya flour based blends (Lin et al., 1974).

Water absorption capacity: The mushroom flour showed higher water absorption capacity $29.333 \%$ followed by black gram flour $25.333 \%$ and refined wheat flour showed lowest water absorption capacity $10.667 \%$. The mixed flour level increased $2.5 \%, 5 \%$ and $7.5 \%$ than water absorption capacities also increased $10.333 \%, 10.643 \%$ and $11.667 \%$ respectively. It was due to lipophilic environment of fat and protein. Water absorption capacity is a critical function of protein for various food products like dough and biscuits baking. The wheat blends from wheat, soy and cassava flours respectively to increased water absorption with increased soy flour fortification (Amarjeet et al., 1995).

Fat/oil absorption capacity: From Table 2, refined wheat flour showed highest value of 
fat/oil absorption capacity (153\%) followed by mushroom flour $(150 \%)$ while black gram flour showed very low fat/oil absorption $(106.667 \%)$ as compared to other samples. If the mixed flour composition level is increased $2.5 \%, 5 \%$ and $7.5 \%$ than the fat/oil absorption is decreased $78.333 \%, 63.333 \%$ and $48.333 \%$ respectively. It was observed that the oil absorption capacity of defatted samples was better than full fat samples. It was due to flour blend protein to physically bind with fat by capillary attraction and it is of great importance since fat acts as flavour retainer and increase the mouth feel of foods. The oil absorption capacity of different levels of blend values compared with other flours and described defatted flours have more fat/oil absorption capacity investigated by (Oshodi $e t$ al., 1997). The soybean flour had a greater capacity to absorb water and oil was described by (Akubor and Ukwuru, 2005).

Foam capacity and foam stability: Foam capacity of mushroom flour rated highest value $(52.667 \%)$ followed by black gram flour $42.667 \%$ and jowar (sorghum) showed very poor $16 \%$. The mixed flour level was increased $2.5 \%, 5 \%$ and $7.5 \%$ than the foam capacity was decreased from $34.667 \%, 34 \%$ and $28 \%$ respectively. It was caused by some anti-nutritional factor involved in foam generation; it is useful functional properties for biscuits and food products development. The good foam ability with flexible protein molecules, which reduces surface tension. Low foam ability on the other hand can be related to highly order the globular proteins, which resists surface of denaturation discussed by (Graham and Phillips, 1976). From Table 2, foam stability of black gram flour was very high $32 \%$ followed by full fat soy flour $10.667 \%$ but refined wheat flour had very poor foam stability $4.667 \%$. Due increase in the level of mixed flours from $2.5 \%, 5 \%$ and $7.5 \%$, foam stability was also increased $3.0 \%$, $5.333 \%$ and $13.333 \%$ respectively. This is occurred by some fat and protein interaction. Foam contributes to smoothness; lightness, flavor dispersions and palatability. The results obtained from the current study indicate that the samples could serve as potential replacements of known proteins in food applications requiring high foam ability and stability for cakes, breads and other bakery products. Some research work by (Sathe et al., 1982; Aluko and Yada, 1995) reported $\mathrm{pH}$ dependency of foam capacity and stability in lupin, winged bean, sunflower and cowpea seed proteins, the better foam stability in acidic condition and poor foam stability at alkaline or basic condition.

Table 2 Functional properties of the different composition of flour

\begin{tabular}{|l|l|l|l|l|l|l|l|l|}
\hline Sample & SWC (\%) & WAC (\%) & \multicolumn{7}{|c|}{ OAC (\%) } & FC (\%) & FS (\%) & EA (\%) & ES (\%) \\
\hline \multicolumn{7}{|c|}{ Individual flours } \\
\hline $\mathrm{M}_{100}$ & $27.66 \pm 0.57$ & $29.33 \pm 0.57$ & $150.00 \pm 10.00$ & $52.66 \pm 3.05$ & $10.00 \pm 2.00$ & $47.18 \pm 1.04$ & $52.28 \pm 1.85$ \\
\hline $\mathrm{B}_{100}$ & $43.00 \pm 1.00$ & $25.33 \pm 0.57$ & $106.66 \pm 5.77$ & $42.66 \pm 3.05$ & $32.00 \pm 2.00$ & $66.53 \pm 1.54$ & $63.36 \pm 0.90$ \\
\hline $\mathrm{S}_{100}$ & $24.66 \pm 0.58$ & $19.66 \pm 0.58$ & $126.66 \pm 11.55$ & $22.00 \pm 2.00$ & $10.66 \pm 1.15$ & $81.48 \pm 1.74$ & $76.10 \pm 2.17$ \\
\hline $\mathrm{J}_{100}$ & $15.66 \pm 0.58$ & $18.66 \pm 0.58$ & $120.00 \pm 10.00$ & $16.00 \pm 2.00$ & $8.66 \pm 2.31$ & $52.33 \pm 1.34$ & $53.83 \pm 2.06$ \\
\hline $\mathrm{W}_{100}$ & $16.66 \pm 0.58$ & $10.66 \pm 1.18$ & $153.33 \pm 5.77$ & $33.33 \pm 3.05$ & $4.66 \pm 1.15$ & $45.04 \pm 1.25$ & $58.00 \pm 2.00$ \\
\hline \multicolumn{7}{|c|}{ Composite flours } \\
\hline $\mathrm{W}_{90} \mathrm{CF}_{2.5}$ & $16.33 \pm 0.58$ & $10.33 \pm 0.58$ & $78.33 \pm 2.88$ & $34.66 \pm 3.05$ & $3.00 \pm 1.00$ & $46.66 \pm 1.27$ & $52.91 \pm 1.50$ \\
\hline $\mathrm{W}_{80} \mathrm{CF}_{5}$ & $17.33 \pm 0.58$ & $10.64 \pm 1.00$ & $63.33 \pm 5.77$ & $34.00 \pm 2.00$ & $5.33 \pm 1.15$ & $45.33 \pm 1.25$ & $52.63 \pm 1.23$ \\
\hline $\begin{array}{l}\mathrm{W}_{70} \\
\mathrm{CF}_{7.5}\end{array} 19.33 \pm 0.58$ & $11.66 \pm 0.58$ & $48.33 \pm 7.63$ & $28.00 \pm 2.00$ & $13.33 \pm 3.05$ & $40.00 \pm 1.18$ & $50.51 \pm 0.66$ \\
\hline $\mathrm{CD}_{0.5}$ & 1.01 & 1.38 & 14.16 & 3.96 & 3.05 & 3.53 & 2.05 \\
\hline $\mathrm{SEm}$ & 0.33 & 0.45 & 4.62 & 0.99 & 0.99 & 1.15 & 0.67 \\
\hline & & & & & & & \\
\hline
\end{tabular}


Description:

$\mathrm{M}_{100}$ : Mushroom flour

$\mathrm{B}_{100}$ : Black gram flour

$\mathrm{S}_{100}$ : Soy flour

$\mathrm{J}_{100}$ : Jowar flour

$\mathrm{W}_{100}$ : Wheat flour (Control)

$\mathrm{W}_{90} \mathrm{CF}_{2.5}=$ Wheat flour $(90 \%)+$ Mushroom flour $(2.5 \%)$

+ Black gram flour $(2.5 \%)+$ Soybean flour $(2.5 \%)+$

Jowar flour $(2.5 \%)$

$\mathrm{W}_{80} \mathrm{CF}_{5.0}=$ Wheat flour $(80 \%)+$ Mushroom flour $(5 \%)+$

Black gram flour $(5 \%)+$ Soybean flour $(5 \%)+$ Jowar flour $(5 \%)$

$\mathrm{W}_{70} \mathrm{CF}_{7.5}=$ Wheat flour $(70 \%)+$ Mushroom flour (7.5\%)

+ Black gram flour $(7.5 \%)+$ Soybean flour $(7.5 \%)+$

Jowar flour (5\%)

SWC $=$ Swelling water capacity

WAC $=$ Water absorption capacity

OAC $=$ Oil absorption capacity

$\mathrm{FC}$ and $\mathrm{FS}=$ Foam capacity and Foam stability

$\mathrm{EA}$ and $\mathrm{ES}=$ Emulsion activity and Emulsion stability

Emulsion activity and Emulsion Stability: Emulsion activity (Table 2) of the full fat soya flour found highest value (81.483\%) followed by black gram flour $(66.537 \%)$ but refined wheat flour with minimum $(45.043 \%)$ as compared to other flour samples. If the mixed flour level is increased the emulsion activity is decreased. The prosperities of emulsion activity were influenced by many factors like capacity of protein, $\mathrm{pH}$, concentration and solubility. These are beneficial for formation and stabilization of emulsions in biscuits baking. From Table 2, The full fat soya flour had highest value of emulsion stability (76.103\%) followed by black gram $63.367 \%$ but mushroom flour showed lowest stability $52.183 \%$ in comparison to taken individual flour. If the flour composition level is increased to $2.5 \%, 5 \%$ and $7.5 \%$ then the emulsion stability decreased to $52.91 \%$, $52.633 \%$ and $50.513 \%$ respectively. Emulsion stability is important phenomena for thick consistency in biscuits baking.

\section{Conclusion}

The incorporation of legume to cerealbased products could be a good alternative for increasing the intake of legumes. In addition, legume proteins are rich in lysine and deficient in sulphur containing amino acids, whereas cereal proteins are deficient in lysine. Mushrooms are a low-calorie high protein diet, with no starch and sugars therefore called the diabetics delight. These are also rich in vitamins and minerals especially B -Complex and iron. Pulses are valued for their protein content as well as their low glycemic index and are commonly included in diets in the Indian subcontinent. Soybeans and soy-based foods are extensively consumed in the Asian diet. In recent years, food legumes have attracted a great deal of attention due to their functional components and health-promoting effects in relation to the prevention of chronic diseases, including cardiovascular diseases, obesity and diabetes. Sorghum grain being an excellent source of many valuable nutrients, such as soluble and insoluble dietary fibers, vitamin B complex, minerals and phenolic compounds, is also a desirable ingredient in baked products.

\section{References}

1. Adeyemi, I.A., Adabari, B.O., Afolobi, O.A. and Oke, O.L. (1992). Evaluation of some quality characteristics and baking potential of amaranth flour. Nigerian Food Journal, 10: 8-15.

2. Akubor, P.I. and Badifu, G.I.O. (2004). Chemical composition, functional properties and baking potential of African bread fruit kernel and wheat flour blends. International Journal of Food Science Technology, 39: 223-229.

3. Akubor, P.I. and Ukwuru, M.U., (2005). Functional properties and biscuit making potential of soybean and cassava flour blends. Plant Foods for Human Nutrition, 58(3):1-12.

4. Akubor, P.I., Achi, O.K. and Onimawo, I.A. (2001). Functional properties of cowpea and maize flour blends. Journal Manag of Technology, 3: 220-225.

5. Akubor, P.I., Adamolekun, F.A., Oba, C.O. and Obari, I.T. (2003a). Chemical composition and functional properties of cowpea/plantain flour 
blends cookie production. Plant Foods for Human Nutrition, 58: 1-9.

6. Akubor, P.I., Benje, F.N. and Obiegbuna, J.E. (2003b). Effects of cowpea supplementation on the functional and biscuit making properties of wheat flour. Journal of Sustainable Agriculture and Environment, 5: 247-253.

7. Aluko, R.E. and Yada, R.Y. (1995). Structure and function relationships of cowpea (Vigna unguiculata L.) globulin isolate. Influence of $\mathrm{pH}$ and $\mathrm{NaCl}$ on physicochemical and functional properties. Food Chemistry, 53: 259-265.

8. Amarjeet, K., Bhupendar, S. and Sidhu, J.S. (1993) Studies on bread and durum wheat blends. Chemical Microbiology Technology Lebensm, 15: 35-40.

9. Amarjeet, K., Sidhu, J.S. and Singh, B. (1995). Effect of enzyme active Soya flour and sodium streroyl -2lactylate additions on white bread making properties. Chemical and Microbial Technology Lebensm, 17(314):105-109.

10. Anjum, F.A., Ahmad, I., Butt, M.S., Sheikh, M.A. and , I. (2005). Amino acid composition of spring wheat's and losses of lysine during chapatti baking. Journal of Food Composition and analysis, 18: 523-532.

11. AOAC (2000). Official methods of analysis of AOAC International $\left(17^{\text {th }}\right.$ ed.). Gaitherburg. USA: AOAC International Inc.

12. Ayo, J.A. (2001). The effect of amaranth grain flour on the quality of bread. International Journal of Food Properties, 4: 341-351.

13. Ayo, J.A. and Gaffa T. (2002). Effect of undefatted soybean flour on the protein content and sensory quality of "Kunnu Zaki". Nigerian Food Journal, 20: 7-9.

14. Chau, C.F.and Cheung, P.C.K. (1997). Functional properties of flours prepared from three Chinese indigenous legume seeds. Food Chemistry, 61: 429-433.

15. Dasappa, I., Sai Manohar, R., Jyotsna, R. and Venkateshwara Rao, G. (2004). Finger millet biscuits and a process for preparing the same. US Patent, No.0191386, A1.

16. Eneche, E.H. (1999). Biscuit making potential of millet/pigeon pea flour blends. Plant Foods for Human Nutrition, 54: 21-27.

17. Ghobel, R.E., Kamoun, A., Neifer, M., Belguith, S., Ayadi, M.A., Kamoun, A. and Choabouni, S.E. (2010). Development of fibre enriched biscuits formula by a mixture design. Journal of Texture Studies, 41: 472-491.

18. Gomez, M., Oliete, B., Rosell, C.M.M., Pando, V. E. and Fernandez (2008). Studies on cake quality made of wheat-chickpea flour blends. Lebensmittel Wissenchaft and Technologie (LWT), 20:1-9.

19. Graham, D.E. and Phillips, M.C. (1976). Foams. Academic Press, London. p. 237.

20. Iyer, L. and Singh, U. (1997). Functional properties of wheat and chickpea composite flours. Food Australia, 49: 27-31.

21. Jones, D., Chinnaswamy, R., Tan, Y. and Hanna (2000). Physiochemical properties of ready-to-eat breakfast cereals. Cereal Foods World, 45:164168.

22. Khader, V. (2001). Textbook of Food Science and Technology. ICAR New Delhi.

23. Khatkar, B.S. (2005). Trends in cereal processing. Beverage Food World, 32(11): 65-67.

24. Lin, M.J.Y., Humbert, E.S. and Sosulski, F. (1974). Certain functional properties of sunflower meal products. Journal of Food Science, 39: 368.

25. Livingstone, A.S., Feng, J.J. and Malleshi N.G. (1993). Development and nutritional quality evaluation of 
weaning foods based on malted, popped and dried wheat and chickpea. International journal of Food Science Technology, 28: 35-43.

26. Mojisola Edema, O., Sanni Lateef, O., and Sanni, Abiodun I. (2005). Evaluation of maize-soybean flour blends for sour maize bread production. Nigeria African Journal of Biotechnology, 4(9): 911-918.

27. Narayana, K. and Narasinga Rao, M.S. (1982) Functional properties of raw and heat processed winged bean flour. Journal Food Science, 47:1534-1538.

28. Okaka, J.C. and Isieh, M.I. (1990). Development and quality of cowpeawheat biscuits. Nigerian Food Journal, 8: 57-63

29. Okaka, J.C. and Potter, N.N. (1977). Functional and storage properties of cow pea-wheat flour blends in bread making. Journal of Food Science, 42: 828-833.

30. Oladunmaye, O.O., Akinoso, R. and Olapade, A.A. (2010). Evaluation of some physical-chemical properties of wheat, cassava, maize and cowpea flour for bread making. Journal of Food Quality, 33: 693-708.

31. Oshodi, A.A., Ipinmoroti, K.O. and Adeyeye, E.I. (1997). Functional properties of some varieties of African yam bean (Sphenostylis sternocarpa L.). International Journal of Food Science and Nutrition, 48: 243-250.

32. Osundahunsi, F.O., Bunde, M.C. and Akinoso, R.(2003). Supplementation of biscuit using rice bran and soya bean flour. AJFAND, 10 (9): 47-59.

33. Rehman, S.U., Paterson, A., Hussain, S., Murtaza, M. A. and Mehmood, S. (2007). Influence of partial substitution of wheat flour with vetch (Lathyrus sativus L.) flour on quality characteristics of doughnuts. LWTFood Science and Technology, 40: 7382.

34. Ruales, J. and Nair, M. (1992). Nutritional quality of the protein in quinoa seeds. Plant Foods for Human Nutrition, 42: 1-11.

35. Sathe, S.K., Deshpande, S.S. and Salunkhe, D.K. (1982). Functional properties of winged bean (Psophocarpus tetragonolobus, L) proteins. Journal of Food Science, 47: 503-506.

36. Shuda, M.L., Vetrimani, R. and Leelavathi, K. (2007). Influence of fibre from different cereals on the rheological characteristics of wheat flour dough and on biscuit quality. Food chemistry, 100: 1365-1370.

37. Sosulski, F.W., Garatt, M.O. and Slinkard, A.E. (1976). Functional properties of ten legume flours. International Journal of Food Science Technology, 9: 66-69.

38. Yasumatsu, K., Sawada, K., Moritaka, S., Mikasi, M., Toda, T. and Tshi, K. (1972). Whipping and emulsifying properties of soybean products. Agricultural Biochemistry, 36:719727. 